\title{
Criminal Action Without Proven in Money Laundering in Indonesia
}

\author{
Fadel Ilato ${ }^{1}$ \\ Abdul Majid ${ }^{2}$ \\ Setiawan Noerdajasakti ${ }^{3}$
2 Faculty of Law, Universitas Brawijaya, Indonesia. E-mail: abdul.madjid@ub.ac.id
${ }^{3}$ Faculty of Law, Universitas Brawijaya, Indonesia. E-mail: sakti@ub.ac.id \\ ${ }^{1}$ Faculty of Law, Universitas Brawijaya, Indonesia. E-mail: fadelilato@student.ub.ac.id
}

\begin{abstract}
Article Info
Keywords:

Predicate Crime, Without Proof, Money Laundering Crime.

How to cite (APA Citation Style):

Ilato, Fadel., et. Al. (2021). "Criminal Action Without Proven in Money Laundering Indonesia". Jambura Law Review. JALREV 3 Special Issue: 180-197
\end{abstract}

\begin{abstract}
Money laundering is a follow-up crime, an underlying crime from a predicate crime, so that the existence of money laundering cannot be separated from the original crime. How can money laundering occur without proving the original crime? Therefore, the aim of this study is to analyze the legal implications of predicate offenses without substantiation in money laundering in Indonesia. This research is juridical-normative research, which uses a statutory approach and a case approach. The results of this study indicate that there are legal implications for predicate offenses without proof in money laundering in Indonesia. Starting from breaking through the presumption of innocence and inconsistencies in legal norms in the TPPU Law. So, it is necessary to change the construction of norms contained in article 69 related to proving predicate crimes in TPPU.
\end{abstract}




\section{Introduction}

The development of increasingly advanced times has had a significant impact on the struggles of the world community. These developments can change people's lifestyle from conventional methods to modern in all fields, political, economic, social, cultural, military, consumptive technology, and other fields. The development of these civilizations began to accumulate by the accumulation and interaction between their processors, with the agricultural revolution and after them lived in large numbers and settled. In addition, the role of technology also affects the escalation of the development of civilization, whose development has increased in various sectors with the industrial revolution. ${ }^{1}$

Related to the escalation of the development of civilization can be a serious challenge to society itself, one of which is by participating in the development of a conventional crime into a crime whose entity is even more modern so that the modern form of crime management is needed the implementation of criminal justice that is also following the changes of the era. Concretely, more gradually, the Criminal Justice System can be studied through the approach of legal dimensions, sociology, economics, and management, as well as the assumption and description of Satjipto Rahardjo that there are several options to review a legal institution such as the criminal justice system, namely with a legal approach and with a broader approach, such as sociology, economics, and management. In terms of professionals, SPP is commonly discussed as a stand-alone legal institution. Here we pay attention to the principles, doctrines, and laws governing criminal justice. In legal science, such an approach is called positivist-analytical. ${ }^{2}$ This approach became a progressive theory in the criminal justice system to overcome all forms of crime that keep up with the times.

Crime management through the implementation of criminal justice, which is the work of law enforcement officials, either start the process of investigation and

1 Jacob, T. (1988). Manusia, Ilmu dan Teknologi Pergumulan abadi Dalam Perang dan Damai. Yogyakarta: Tiara Wacana, p. 19.

2 Rahardjo, S. (1998). Sistem Peradilan Pidana Dalam Wacana Kontrol Sosial, Jurnal Hukum Pidana Dan Kriminologi. Bandung: Citra Aditya Bakti, p. 97. 
investigation, arrest, detention, prosecution, until the examination in front of a court hearing, or it can be said that the work of police, prosecutors, judges, and correctional officers, which also means the process of the work of criminal event law. ${ }^{3}$ The purpose of the criminal justice system can be formulated as follows: (a) prevent the public from becoming victims of crime; (b) resolve the case of a crime that occurred so that the public is satisfied that justice has been served and the guilty are convicted, and (c) make sure that those who have committed a crime do not repeat their crimes. ${ }^{4}$ To realize these goals, an integrated criminal justice system is needed.

As the author said earlier, the purpose of criminal justice is inseparable from how criminal justice can overcome the crimes that arise along with the rapid development of the adult world today. One of the crimes that are rife with participating in the development of changing adults today is the crime in the economic field, among others, the process of money laundering (money laundering). According to data from the Center for Reporting and Analysis of Financial Transactions (PPATK), from 2014 to October 2017, there were 857 exchanges of information related to money laundering (TPPU) crimes between PPATK and financial intelligence units of other countries. ${ }^{5}$

As the author said earlier, the purpose of criminal justice is inseparable from how criminal justice can overcome the crimes that arise along with the rapid development of the adult world today. One considers that money laundering entities are transnational crimes (transnational crime) whose mode is widely carried out to cross state borders. The implications of this money laundering practice significantly affect the financial system's stability and the world economy. This includes negative impacts on the effectiveness of the use of resources and funds. Therefore, the Financial Action Task Force (FATF) On Money Laundering has issued an international standard that is a measure for every Country/jurisdiction in the prevention and eradication of money laundering and terrorism financing crimes known as Revised 40

3 Anwar, Y. dan Adang. (2011). Sistem Peradilan Pidana Konsep, Komponen, \& Pelaksanaannya dalam Penegakkan Hukum di Indonesia. Bandung: Widya Padjadjaran, p. 28.

4 Atmasasmita, R. (2011). Sistem Peradilan Pidana Kontemporer. Cetakan ke-2. Jakarta: Kencana, p. 3.

5 Kompas. Tindak Pidana Pencucian Uang Lintas Negara Semakin Marak. Retrieved from https://www.kompas.id/baca/utama/2018/10/31/tindak-pidana-pencucian-uang-lintas-negarasemakin-marak/ (accessed January 20, 2020). 
Recommendations And 9 Special Recommendations (Revised $40+9$ ) FATF and if there is a waiver to this FATF then result in a State will be included in the list of noncooperative countries and territories. ${ }^{6}$

The birth of the anti-money laundering regime was marked by the release of the 1998 Vienna convention (The United Nation Convention Against Illicit Trafic In Narcotics, Drugs And Psychotropic Substances of 1998), which became the forerunner of history for the attention of the international community who were serious about eradicating the practice of money laundering. The objective of the international regime is to regulate and supervise certain transactions and their activities by conducting international legal and institutional procedures, and this regime has subregimes tasked with regulating the flow of international funds, including anti-money laundering provisions. ${ }^{7}$

Indonesia itself, the regulation against the regime, anti-money laundering was first regulated in Law No. 15 of 2002 on Money Laundering Crimes as amended by Law No. 25 of 2003 and most recently has been regulated under Law No. 8 of 2010 on Prevention and Eradication of Money Laundering Crimes which is further shortened to PP-TPPU Law. ${ }^{8}$

The crime of its origin in the PP-TPPU Law is regulated in Article 2 paragraph (1) from point a to point $\mathrm{z}$. The formulation of various crimes is expressive verbis qualified as a criminal offense that can do money laundering practices and added to point $\mathrm{z}$ related to criminal acts whose criminal threats are as much as four years and above. ${ }^{9}$

6 Gresnews. Ini Kerusakan yang Ditimbulkan Akibat Praktik Pencucian Uang. Retrieved from http://www.gresnews.com/berita/hukum/90044-ini-kerusakan-yang-ditimbulkan-akibat-praktikpencucian-uang/ (accessed January 20, 2020)

7 Ganarsi, Y. (2003). Kriminalisasi Pencucian Uang (Money Loundring). Cetakan ke-1. Jakarta: Program Pascasarjana Fakultas Hukum Universitas Indonesia, p. 137.

8 The term regime is commonly used in various international references to anti-money laundering, including the recognized international standard, the 40+9 FATF Recommendations. The notion of the regime has nothing to do with politics or power because, in essence, the term regime has a neutral understanding, namely as a system. See Husein, Y. (2007). Rezim Anti Pencucian Uang Indonesia dan Implikasinya Terhadap Profesi Notaris, dalam Bunga Rampai Anti Pencucian Uang. Bandung: Books Terrace \& Library, p. 170.

${ }^{9}$ Article 2 paragraph (1) of Law No. 8 of 2010 on Prevention and Eradication of Money Laundering. 
Criminalizing such acts can be interpreted as an attempt not to provide opportunities for criminals to enjoy the results of wealth obtained from the proceeds of crime. This effort is helpful as an embodiment of preventive measures to eradicate a criminal act by making it unprofitable. This can be due to other acts such as placing, transferring, transferring, spending, paying, granting, leaving, taking abroad, changing shape, exchanging currency or securities, hiding or disguising, receiving or controlling property that is the result of a criminal act of origin is a criminal offense in itself. ${ }^{10}$

Looking further, related to the predicate crime in an article, a quo that the author has listed has very clearly interpreted the position of the original crime in the money laundering crime. However, what is still a problem in its position as a criminal act of origin is the process of proving the original criminal Act. The basis of the author states that there is a problem that is so severe related to the position of the original criminal activity in the process of proof is that the author refers to the formulation of the norm listed in article 69, which states that:

"To be able to conduct investigations, prosecutions, and examinations in court hearings against money laundering crimes must not be proven in advance the original crime."

The phrase does not necessarily prove to define clearly that the process of proving the original criminal Act becomes unnecessary or, in other words, that the position of the original criminal Act contained in the preceding articles does not require an element of proof. This is undoubtedly something that saves the problem juridically. Because how can money laundering practices occur if the original criminal Act is not proven. As the author has outlined earlier that in principle, the criminal activity of money laundering is a continuation of the original criminal Act.

A person is charged with money laundering but is not based or does not refer to the occurrence or proven crime of origin. Then, of course, this is contrary to the principle of presumption of innocence that has been explained in the general explanation of the Criminal Procedure Law 3rd point C. According to Yahya Harahap, the basic definition

10 Vide Article 3, Article 4, and Article 5 of Law No. 8 of 2010 on Prevention and Eradication of Money Laundering. 
of presumption of innocence is that a suspect must be placed in a human position with the 3rd point of innocence. The truth of dignity. He should be judged as a subject who is examined not a suspect human, but a criminal act that he committed that was used as the object of examination towards the criminal error carried out by the examination. The suspect must be considered innocent until a court ruling has been obtained that has permanent legal force. ${ }^{11}$

\section{Problem Statement}

In this article, the author wants to outline the importance of proving the original criminal activity in the money laundering crime so that in addition to not touching the principle of presumption of innocence, it also does not experience inconsistencies in legal norms in the PP-TPPU Law itself. Therefore, it is necessary to identify the legal implications of predicate crime in money laundering crimes that do not require an element of proof.

\section{Methods}

This article is the result of research. Looking at the legal issues studied in this study, it can be ascertained that this research is included in juridical-normative legal research by using 2 (two) approach methods to answer problems following the formulation of problems that have been established before, namely with the statute approach and case approach.

\section{Legal Implications of Predicate Crime in Money Laundering Crimes That Do Not Require an Element of Proof}

The Constitution of the Republic of Indonesia in 1945 (after this written the Indonesian Constitution of 1945), which is the Constitution of the Indonesian state of the Republic of Indonesia the result of the third amendment expressly in Article 1 paragraph (3) affirms that the State of Indonesia is a state of Law or Rechtstaat. It powerfully interprets that Indonesia is a very democratic state of Law by sticking to Pancasila and the 1945 Indonesian Constitution, upholding human rights, upholding

11 Harahap, M. Y. (2012). Pembahasan Permasalahan dan Penerapan KUHAP Pemeriksaan Sidang Pengadilan, Banding, Kasasi, dan Peninjauan Kembali. Jakarta: Sinar Grafika, p. 36. 
Law and government, and guaranteeing all citizens equally their position before the Law and government. Therefore, the Law should be used as commander-in-chief and as a foundation based on the whole effort to organize and solve every problem of national and state life in order to realize the noble ideals of a safe, prosperous, and equitable life of the nation and state in every sector.

In the context of the current legal state, the Indonesian state must place the Law on supreme power as the basis of a state that is aligned, in harmony, and harmony with the development of Law. Legal development is directed at realizing a stable legal system that includes the development of legal materials, legal structures, including legal apparatus, legal facilities, and infrastructure, the realization of a society with high legal awareness and culture to realize a legal state. ${ }^{12}$

Legal development is carried out through the renewal of the Law while keeping in mind the plurality of the prevailing legal order and the influence of globalization. Such conditions are an effort to increase certainty, awareness, service, and law enforcement in the course of justice, disorganization, order, and welfare in the framework of the implementation of an increasingly orderly and orderly state. ${ }^{13}$

Contemporary legal development in Law or Reschstaat is very closely related to law enforcement in Indonesia. Law enforcement is central to all legal "life activities" across law planning, law enforcement, and legal evaluation. Law enforcement is essentially an interaction between various human behaviors that can represent different interests within the framework of mutually agreed rules. ${ }^{14}$

Law enforcement must essentially be aligned with the enforcement of human rights. In the context of anti-money laundering enforcement, the application approach relating to the investigation process until the trial in court should reflect the guarantee of the fulfillment of human rights. According to Sri Sumantri, the guarantee of the fundamental rights of every citizen means that every ruler in the state cannot

12 Wantu, F. M. (2011). Idee Des Recht: Kepastian Hukum, Keadilan Dan Kemanfaatan (Implementasi Dalam Proses Peradilan Perdata). Yogyakarta: Pustaka Belajar, p. 1.

13 Ibid.

14 Fakrulloh, Z. A. (2005). "Penegakan Hukum Sebagai Peluang Menciptakan Keadilan". Jurnal Jurisprudence, 2 (1): 22 
and should not act arbitrarily to his citizens, even the existence of fundamental rights also means a balance in the state, namely the balance between power in the state and the fundamental rights of citizens. ${ }^{15}$

The necessity of the balance of the fulfillment of the rights of citizens in the state as a form of control over the power of such a state. In this case, concerning the enforcement of criminal law, there is a doctrine of equality of arms based on the circumstances of the suspect/ defendant who is very unbalanced (disadvantage) in facing the state. Through the police and prosecutors, the state always has a more incredible opportunity than the opportunity that the suspect/ defendant has. ${ }^{16}$ According to Muladi, the criminal justice system is a judicial network that uses criminal Law as its primary means, both material criminal law, criminal Law formal, and criminal implementation law. Nevertheless, these substantial institutions must be viewed in a social framework or context. Its nature that is too formal if based only on the interests of legal certainty will lead to injustice.

Control of the vast power of the state through its law enforcement officers can be exercised if the rights of suspects or defendants are contained in a norm contained in a product of legislation. Observing this is correlated with the sound of Article 69 of Law No. 8 of 2010 on the prevention and eradication of money laundering crimes that essentially override the process of proving criminal acts of origin first in the enforcement of money laundering crimes. While basically, related to the criminal activity of money laundering is a follow-up criminal offense of its original crime. How can money laundering be processed without first processing or proving the crime of origin? Alternatively, do the proof process simultaneously. Thus, if so the construction of the norms contained in article $a$ quo, it can be directly said that there has been amputation of the recognition of fundamental human rights, in this case, the recognition of the rights of the suspect or the accused.

A critical review of the sound of article 69 related to the sentence "not obliged to be

15 Soemantri, S. (1992). Bunga Rampai Hukum Tata Negara Indonesia. Bandung: Alumni, p. 74.

16 Reksodiputro, M. (1999). Hak Asasi Manusia dalam Sistem Peradilan Pidana, Kumpulan Karangan Buku ke Tiga. Jakarta: Pusat Pelayanan Keadilan dan Pengabdian Hukum, Lembaga Kriminologi Universitas Indonesia, p. 37-38. 
proven in advance criminal offense of origin," the phrase "not mandatory" here clearly confirms that against the crime of origin in the criminal activity of money laundering does not require an element of proof. This undoubtedly saves the problem juridically that is contrary to the principle of presumption of innocence. The presumption of innocence is essentially a manifestation of the function of modern criminal justice that commits violent expropriation or revenge of an institution designated by the state. As such, all rights violations committed by a person must be resolved following applicable legal procedures. This principle states that. "Any person who is suspected, arrested, detained, prosecuted, and/or confronted before a court must be presumed innocent before the verdict of the Court, which declares his guilt and obtains permanent legal force."17

According to Oemar Senoadji, the presumption of innocence generally manifests itself in the burden of proof, burden of proof. The public prosecutor should prove the accused's guilt unless instant proof is charged to the accused or the Law provides a strict provision of reverse proof. ${ }^{18}$ The consequence of the presumption of innocence is that a suspect or Defendant accused of a criminal offense should not be treated as a guilty person even though he may be subject to arrest/ detention under applicable Law. So, all parties, including law enforcement, must still uphold the human rights of suspects/ defendants.

Everyone should be "guaranteed the right to self, residence, letters of unwarranted examination and confiscation. The right of confrontation in the form of crossexamination with the accused or reporting person, the right to obtain the prompt examination, the right to equal protection and equal treatment in Law, the right to legal counsel assistance. ${ }^{19}$ This thought is reinforced by the theory of social defense, put forward by Grammatica, who states that social protection law must replace the existing criminal law, in a paper entitled La lotta contra la pen so that a criminal is

17 Tahir, H. (2010). Proses Hukum Yang Adil Dalam Sistem Peradilan Pidana di Indonesia. Yogyakarta: LaksBang PRESSindo, p. 17.

18 Adji, O. S. (1981). Hukum Acara Pidana dalam Prospeksi. Jakarta: Erlangga, p. 251.

19 Harahap, M. Y. (2000). Pembahasan Permasalahan dan Penerapan KUHAP: Penyidikan dan Penuntutan. Jakarta: Sinar Grafika, p. 21. 
reintegrated into society instead of being criminally charged against his actions. ${ }^{20}$

The above description places the principle of presumption of innocence is closely related to the criminal justice process, which is a process in which a person becomes a suspect with the use of arrest until a judge's verdict declares his guilt. It can be said that the indicator of the application of the principle of presumption of innocence is in the process of investigation, especially in arrest and detention, in the process of prosecution and examination in the trial so that the presumption of innocence contains the understanding that even if a person is strongly suspected of committing a criminal act in the sense of sufficient evidence and ultimately punished, they should still be valued for their human rights. It can be imagined that if the suspect or Defendant was treated inhumanely during the examination, and more so after trial, it turned out that Defendant was innocent.

The phrase "not obligatory" contained in article 69 of the Law a quo by eliminating the process of proof in the enforcement of anti-money laundering laws certainly touched the basic principles of presumption of innocence as previously outlined. The word not in Article 69 is not appropriate and can be interpreted with a meaning that is contrary to the sound in Article 3, Article 4, and Article 5 paragraph (1) of Law $8 / 2010$, which in principle states that to be able to prosecute a person with a criminal charge of Money Laundering, then the property must be the result of one or several original criminal acts (predicate crimes or predicate offenses), in other words, there is no money laundering crime if there is no crime of origin (predicate crimes or predicate offense). Thus, if a person is charged with money laundering, it does not refer to or is not based on the case. The proven crime of origin (predicate crimes or predicate offense) contradicts the principle of presumption of innocence described in the General Explanation of the Criminal Procedure Law item 3 letter c and Article 8 paragraph (1) of the Law of Justice. This can be seen with the provisions of Article 2 which clearly qualifies the type of crime that is potentially caused by the occurrence of money laundering so that it is hereinafter referred to as an act. Furthermore, it can also be found in the provisions of Article 3, Article 4, and Article 5 which criminalizes

${ }^{20}$ Arief, B. N. (1994). Kebijakan Legislatif dalam Penanggulangan Kejahatan. Semarang: BP Undip. p. 29. 
the acts of the perpetrators who enjoy the results of the regular inconsistency of laundering. Aside from the articles presented by the author, TPPU also recognizes the existence of a system of reversal of the burden of proof.

Related to the discussion above, it becomes the carrying capacity of the author to analyze a case that has permanent legal force. Based on the construction of norms contained in Article 69 of the Act, it is not mandatory to first prove the original criminal Act of money laundering provides an opening for the public prosecutor to drag money laundering cases to trial on a single charge only. This makes them less effective indictment of prosecutors in the trial on this matter then tends the Judge's verdict will be free (Vrisprakk).

To analyze this can be seen in the case example as follows:

1. Case Position: Initials D.K (Male). Address: Palu Age 35 years/July 30, 1979. Indicted Article 5 paragraph (1) of Law No.8 of 2010, the evidence in question is in the form of 1 (one) bundle of photocopy of account opening transaction documents (Documents) and Savings Banks Accounts (letters) with proof of transfer of Rp.1,913,000,000, - (One Billion Nine Hundred and Thirteen Million Rupiah) with proof of transfer of Rp.1,913,000,000, - (One Billion Nine Hundred and Thirteen Million Rupiah). ${ }^{21}$

The panel of judges who in his legal considerations mentioned:

Weighing; That based on the description of the consideration of the elements fulfilled "Receiving Transfer" Elements that he knows or suspects are the result of criminal acts as referred to in Article 2 Paragraph (1). Based on the proof of the elements of Receiving or mastering the placement, transfer, payment, grant, donation, custody, exchange, or use of property, Defendant, as chairman of KSP Moengko Jaya, has received money from H. A witness, seven times with a value of Rp.1,913,000,000,--Cone billion Nine hundred and thirteen million Rupiah); Weighing; Based on the testimony of several faithful witnesses that received services from investments made with KSP Moengko

${ }^{21}$ Palu District Court Ruling Number: 512/Pid.Sus/2013/PN-Pal. 
Jaya, therefore, based on the above consideration of the element "Which he knows or should suspect is the result of a criminal act as referred to in Article 2 paragraph (1)", Not Fulfilled; that therefore one of the elements of Article 5 paragraph (1) of Law No. 8 of 2010 on Prevention and Eradication of Money Laundering Crimes, is not fulfilled, then under Article 191 paragraph (1) of the Kuhap the accused is not proven to have legitimately convincingly committed a criminal act as charged by the Public Prosecutor and at the same time acquitting the Defendant of the charge.

The author's analysis of the above case that the evidence submitted by the public prosecutor in his indictment is a means of witness testimony and letters (proof of copies of bank transfers) because if applied to the allegations as there is Article 3,4,5 of the Act a quo it should be suspected that "Property allegedly sourced from criminal acts" but in practice, the public prosecutor, in this case, cannot prove that the property obtained by the accused comes from the original criminal Act as stipulated by Article 2 paragraph (1) of the Law a quo. The public prosecutor gave his indictment only the Money Laundering Act only then did not first prove the original case the author had outlined above about the D.K case with Number: 512 / Pid. Sus/2013/PN.PL. The Public Prosecutor in his indictment Article 5 paragraph (1) is only suspected of committing the crime of passive laundering (receiving the flow of funds), but in this case, the public prosecutor is not careful and unable to prove the origin of the property. Therefore, the accused is free from all lawsuits (vrijspraak).

As for the case that the author will describe next, as follows:

2. Case Position: Defendant R.S. is proven to have legitimately and convincingly committed a criminal act of origin of "corruption" Article 2 paragraph (1) letter "a" of Law No.8/2010 then the Criminal Act continues Money Laundering by processing (layering) the transfer of funds to several accounts against deposits and transfers that have been made by the Defendant, whose funds are sourced from account number: 001.01.03. 25597-1 on behalf of the Regional Head Of Cash Holder of Central Sulawesi Province. According to the Panel of Judges, the Defendant's actions are carried out on the same day and 
the same hour or time adjacent to the amount broken up (layering) is the Act of placing, transferring funds from the crime of Corruption committed. It cannot be justified according to the Law because Defendant has no right to the funds that have been deposited and transferred. Moreover, in the trial the Defendant cannot prove or indicate the origin or source of funds contained in the account number: 001.02.01.07634-2, number: 0145611051, number: 151.000.4705-403 and account number: 151,000.5505-489 and number: 79203495425 all in the name of R.S including funds entered into account number: $151,000,4802-879$ on behalf of H.P. Therefore to the Defendant is burdened to account for all funds in question so that the opinion of the Pens The Defendant's Law which in his defense note stated that the origin of the source of money to BNI, Mandiri and BCA accounts during the period 20062010 amounting to Rp.684,000,000.00 (six hundred and eighty-four million Rupiah) was derived from the income and opinion of the husband and wife (Defendant and E.S) for 5 (five) years of work, assuming annual income of Rp.136,800,000.00 (one hundred and thirty-six million eight hundred thousand Rupiah) or Rp.11,400,000.00 (eleven million four hundred thousand Rupiah) should be ruled out; "Who places, transfers, diverts, spends, pays, grantes, leave, takes abroad, changes shape, exchanges for currency or securities or other deeds" has been proven. ${ }^{22}$

Judge's Consideration: Considering that against deposits and transfers that have been made by the Defendant whose funds are sourced from account number: 001.01.03.25597-1 on behalf of the Regional Head of The Central Sulawesi Provincial Head Of Cash Holder, according to the Judge's Panel of Defendant's deeds were carried out on the same day and the same hour or time adjacent to the amount broken (layering) is the Act of placing, transferring funds from the proceeds of criminal Corruption committed, and this cannot be justified under the Law because the Defendant does not have the right to the funds that have been deposited and transferred, moreover in the trial the Defendant cannot prove or show about the origin or source of

${ }^{22}$ Palu District Court Ruling Number 39/Pid.Sus-TPK/2014/PN-Pal. 
funds contained in the Defendant's account.

Considering that based on the facts as already unraveled above, the element "Which places, transfers, diverts, spends, pays, grant, leave, take abroad, change shape, exchange for currency or securities or other deeds" has been proven; Elements of the property that he knows or should be suspected of are the result of criminal acts.

Considering, that in the trial revealed facts based on the testimony of witnesses, expert information and evidence of letters submitted by the Public Prosecutor and the testimony of the Accused that the funds deposited or transferred by the Defendant to the Defendant's savings account amounted to Rp.3,040,650.573.10 (three billion forty million six hundred fifty thousand five hundred and seventy-three Rupiah ten cents) derived from the proceeds of criminal Corruption committed by the Defendant while serving as Treasurer of Expenditure / Treasurer of Expenditure of the Head of Central Sulawesi Province fiscal year 2007 to / d Fiscal Year 2011 (until June 2011), by disbursing funds not in accordance with the spending needs of the Regional Head of Central Sulawesi Province and not in accordance with the provisions of the laws and regulations on regional financial management so that funds that have been disbursed from regional cash funds have been transferred to the account of the regional head's cash holder. Thus, the element "On the property that he knows or should be suspected of being the result of a criminal act" has been proven. Elements; With the aim of hiding or disguising the origin of wealth and considering, that in the trial revealed facts based on the testimony of witnesses, expert testimony, and evidence of letters submitted by the Public Prosecutor as well as the Defendant's testimony that funds deposited or transferred by the Defendant in the Defendant's savings account by way of cash withdrawal from the account in the name of the Regional Cash Holder. Some were done by Defendant when the Defendant served as Treasurer of Expenditure / Treasurer of Expenditure of the Regional Head of Central Sulawesi Province in Fiscal Year 2007 to / d of the Fiscal Year 2011 (until June 2011) so that the funds are the result of criminal acts of Corruption 
because at the time of trial the Defendant was unable to explain the source of the funds contained in the Defendant's savings account. Thus, the element "To conceal or disguise the origin of wealth" has been proven; The Origin Criminal Investigation always adds professionalism in handling cases that are complex, multi-dimensional. Article 74 provisions of Law Number; 8/2010 mentioned, the investigation of TPPU is carried out by criminal investigators of origin following the provisions of the laws and regulations unless otherwise specified under this Law.

Prosecuting: Defendant R.S. is proven to have lawfully and convincingly committed a criminal offense of origin of "corruption" Article 2 paragraph (1) letter "a" of Law No.8/2010 then the Criminal Act continues Money Laundering by processing (layering) the transfer of funds to several accounts as alleged in the first primary indictment and the Second indictment.

In the second case example above, the Public Prosecutor at the same time has proven between the Crime of Origin and the Criminal Act of Money Laundering. This can be seen from the construction of the indictment. Namely, Defendant is charged with charges compiled in combination (Cumulative Subsidiarity). Investigators in conducting investigations have conducted examinations both the collection of evidence and the submission of cases to the public prosecutor together, namely the Crime of Corruption and Money Laundering And then the Public Prosecutor in making an indictment has received and compiled an indictment obtained from investigators in the form of News Of Investigation Events (case files) compiled in the form of combination charges meaning the accused is suspected of committing Criminal Acts of Corruption and Corruption. Money laundering in one indictment.

The Judge who examined and tried the case has considered the elements of the Crime of Corruption and Money Laundering in one examination of the case and has been decided by the Judge in legal considerations, elements of the Crime of Corruption and Money Laundering, in this case, Investigators, public prosecutors, and judges have conducted a joint examination between the Crime of Origin (Corruption) and the Money Laundering Act without having to rely on construction. The legal norms 
contained in article 69 of the Act a quo.

Based on the above description, the author came to the understanding that to avoid the legal implications of the norms contained in article 69 of the $A$ quo Law related to not having to be proven in advance the original criminal Act that touched the principle of presumption of innocence. Because if reviewed in comprehensive terminology about what is meant by money laundering or money laundering in the Black's Law Dictionary, Money Laundering Term used to describe investment or other transfer of money flowing from racketeering, drug transactions, and other illegal sources into legitimate channels so that its original source can be traced.

So ideally about the original criminal Act must be proven first or at least the money laundering crime proven simultaneously with the original criminal Act (concursus realis), which is also contained in the legal theory of criminal events mentioned that these two criminal acts must be charged at once in the form of cumulative charges, not alternative charges or substitutions so that there is not the slightest legal principle in modern justice that is ruled out especially with the U.S. as the presumption of innocence and also against the effectiveness of the quality of proof of money laundering itself. The primary position of presumption of innocence became a vital principle put forward by Friedrich Julius Stahl by characterizing the concept of the state of Law into three characteristics, namely the protection of human rights (grondrecten), the separation or division of power (scheiding van machten), the existence of government based on regulations (wetmatigheid van het bestuur), and the existence of a free administrative judiciary in disputes (administrative rechtspraak). ${ }^{23}$

Therefore, maximizing the approach of asset pursuit and the prosecution of money laundering must be supported by the quality of proof of the original criminal Act. So, according to the author related to the phrase "not obligatory" in the provisions of article 69 of the Act, a quo needs to be removed and sought a new formulation to change the phrase into a single sentence that orders that related to the original

23 Sayuti. (2011). "Konsep Rechtsstaat Dalam Negara Hukum Indonesia". Nalar Fiqh, Jurnal Kajian Ekonomi Islam dan Kemasyarakatan. 4 (2): 93 
criminal Act must be proven first or at least regarding the criminal activity of money laundering proven simultaneously with the original criminal Act.

\section{Conclusion}

The legal implications of the provisions of article 69 related to the sentence "not obliged to be proven in advance criminal offense of origin," the phrase "not mandatory" here clearly confirms that against the crime of origin in the criminal activity of money laundering does not require an element of proof. This is undoubtedly something that saves the problem juridically that is contrary to the principle of presumption of innocence. Furthermore, the phrase "not mandatory" here negates clearly that against the original criminal activity in the criminal activity of money laundering does not require an element of proof, experiencing inconsistencies in criminal law norms in one product of legislation. The crime of money laundering is a follow-up criminal act, underlines crime of a criminal origin (predicate crime), so that money laundering crimes cannot be separated from the original crime. The predicate crime is the forerunner of the crime of money laundering, especially in terms of the pursuit of the assets of criminals. Therefore, maximizing the approach of asset pursuit and the prosecution of money laundering must be supported by the quality of proof of the original criminal Act.

\section{References}

Anwar, Y. dan Adang. (2011). Sistem Peradilan Pidana Konsep, Komponen, \& Pelaksanaannya dalam Penegakkan Hukum di Indonesia. Bandung: Widya Padjadjaran.

Arief, B. N. (1994). Kebijakan Legislatif dalam Penanggulangan Kejahatan. Semarang: BP Undip.

Atmasasmita, R. (2011). Sistem Peradilan Pidana Kontemporer. Cetakan ke-2. Jakarta: Kencana.

Fakrulloh, Z. A. (2005). "Penegakan Hukum Sebagai Peluang Menciptakan Keadilan". Jurnal Jurisprudence, 2 (1)

Ganarsi, Y. (2003). Kriminalisasi Pencucian Uang (Money Loundring). Cetakan ke-1. Jakarta: Program Pascasarjana Fakultas Hukum Universitas Indonesia.

Harahap, M. Y. (2000). Pembahasan Permasalahan dan Penerapan KUHAP: Penyidikan dan Penuntutan. Jakarta: Sinar Grafika. 
Harahap, M. Y. (2012). Pembahasan Permasalahan dan Penerapan KUHAP Pemeriksaan Sidang Pengadilan, Banding, Kasasi, dan Peninjauan Kembali. Jakarta: Sinar Grafika.

Gresnews. Ini Kerusakan yang Ditimbulkan Akibat Praktik Pencucian Uang. Retrieved from http://www.gresnews.com/berita/hukum/90044-ini-kerusakan-yangditimbulkan-akibat-praktik-pencucian-uang/, (accessed January 20, 2020)

Kompas. Tindak Pidana Pencucian Uang Lintas Negara Semakin Marak. Retrieved from $\quad$ https://www.kompas.id/baca/utama/2018/10/31/tindak-pidanapencucian-uang-lintas-negara-semakin-marak/, (accessed January 20, 2020).

Husein, Y. (2007). Rezim Anti Pencucian Uang Indonesia dan Implikasinya Terhadap Profesi Notaris, dalam Bunga Rampai Anti Pencucian Uang. Bandung: Books Terrace\& Library.

Jacob, T. (1988). Manusia, Ilmu dan Teknologi Pergumulan abadi Dalam Perang dan Damai. Yogyakarta: Tiara Wacana.

Muladi. (1995). Kapita Selekta Sistem Peradilan Pidana. Semarang: Badan Penerbit Universitas Diponegoro.

Rahardjo, S. (1998). Sistem Peradilan Pidana Dalam Wacana Kontrol Sosial, Jurnal Hukum Pidana Dan Kriminologi. Bandung: Citra Aditya Bakti.

Reksodiputro, M. (1999). Hak Asasi Manusia dalam Sistem Peradilan Pidana, Kumpulan Karangan Buku ke Tiga. Jakarta: Pusat Pelayanan Keadilan dan Pengabdian Hukum, Lembaga Kriminologi Universitas Indonesia.

Sayuti. (2011). "Konsep Rechtsstaat Dalam Negara Hukum Indonesia”. Nalar Fiqh, Jurnal Kajian Ekonomi Islam dan Kemasyarakatan. 4 (2)

Soemantri, S. (1992). Bunga Rampai Hukum Tata Negara Indonesia. Bandung: Alumni.

Tahir, H. (2010). Proses Hukum Yang Adil Dalam Sistem Peradilan Pidana di Indonesia. Yogyakarta: LaksBang PRESSindo.

Wantu, F. M. (2011). Idee Des Recht: Kepastian Hukum, Keadilan Dan Kemanfaatan (Implementasi Dalam Proses Peradilan Perdata). Yogyakarta: Pustaka Belajar. 